\title{
Design and build expert system applications using forward chaining methods to manage web-based space management
}

\author{
Sabar Rudiarto ${ }^{1}$, Saruni Dwiasnati 1,* and Agung Susilo Yuda Irawan ${ }^{2}$ \\ ${ }^{1}$ Faculty of Computer Science, Universitas Mercu Buana, Indonesia. \\ ${ }^{2}$ Faculty of Computer Science, Program Studi Informatics Engineering, Universitas Singaperbangsa. Indonesia.
}

Global Journal of Engineering and Technology Advances, 2022, 10(02), 009-017

Publication history: Received on 12 July 2021; revised on 18 January 2022; accepted on 07 February 2022

Article DOI: https://doi.org/10.30574/gjeta.2022.10.2.0115

\begin{abstract}
The presence of facilities and infrastructure to support educational activities in tertiary institutions is essential in order to discover the benefits of these facilities and infrastructure for college residents. In a university, space management entails planning, arranging, managing, and controlling the available space. Singaperbangsa University is one of the universities that offers a variety of facilities, including suitable classrooms, hall rooms for events requiring a big audience, and meeting rooms. However, the mechanism for booking conference rooms is still manual. This makes licensing more difficult since they must go back and forth to the division in charge of scheduling and the occurrence of competing schedules, which forces university authorities to repeat the conflicting schedule. The WEB-based Forward Chaining approach is used in this study. The forward chaining method was chosen because it is thought to be suited for space management, which is still done manually in the licensing of space use. Singaperbangsa University's present room loan service procedure is still in manual form, written on paper in a division in charge of documenting it. The recording must still come to the room, but it cannot be done in a more structured fashion to avoid a schedule that uses the room at the same time and in the same location. The data for this study was collected from January to December 2020. SDLC will be used to design the system. The Laravel programming language was used to create this system, while MySQL was used to create the database.
\end{abstract}

Keywords: Expert system; Forward chaining; Laravel; Room loan

\section{Introduction}

The use of information systems is very important in the environment of agencies, organizations, companies, or in the world of education. The educational institution will serve all activities that are directly related to the institution. This is where the role of computer technology that is supported by the use of effectiveness and efficiency is needed. The development of information technology is currently very fast and mushrooming. The development of information technology will not run well without the support of adequate resources. In everyday life, humans cannot be separated from information technology. The university is an institution that closely follows the development of information technology, one of which is in the process of borrowing and borrowing rooms, whether in classrooms, halls, or meeting rooms. There are several opinions regarding the meaning of the system. The system is a group of elements that are integrated with the same intent to achieve a goal [1].

One technique that can be used to make computers capable of processing this knowledge is called artificial intelligence techniques. With this approach, humans try to make computers think like the way humans solve computer problems. Expert System is a branch of Artificial Intelligence (AI) that makes extensive use of knowledge or knowledge specifically for expert human level problem solving [2]. The Expert System consists of two main parts, namely the development

\footnotetext{
${ }^{*}$ Corresponding author: Saruni Dwiasnati

Faculty of Computer Science, Universitas Mercu Buana, Indonesia.

Copyright (C) 2022 Author(s) retain the copyright of this article. This article is published under the terms of the Creative Commons Attribution Liscense 4.0.
} 
environment and the consulting environment [3]. The developer environment in the expert system is used as an entry point for expert knowledge into the expert system environment, while the consulting environment will be used by nonexpert users in obtaining expert knowledge. The research conducted by Hari Nuriyanto and Sabar Rudiarto[4] is to make the fire protection system maintained its quality and the level of safety feasibility can be known. Fires from these buildings, periodic inspections and assessment systems must be carried out objective. For this reason, the author makes an application that makes it easier for officers to check the protection system fire safety measures to determine the feasibility of fire safety in buildings using the method certainty factor in calculating the percentage of values based on android and websites. Another study conducted by Bagus Priambodo and Yuwan Jumaryadi made an expert system application with deception detection in the community in the northern Meruya environment. So that the user does not lie when answering Questions about the symptoms of being exposed to Covid, track record of travel and family history of being exposed covid. This application is expected to be the first alternative to protect health workers from patients without symptom[5].

Forward chaining starts with working with available data and uses inference rules to obtain other data until a goal or conclusion is reached. An inference engine that uses forward chaining searches for inference rules until it finds one of the true antecedents (hypothetical propositions or IF - THEN clauses). When the rule is found, the decision-making engine can make a conclusion, or consequence (THEN clause), which generates new additional information from the data provided. The machine will repeat through this process until the target is found. Forward chaining is an example of a general concept of data-driven thinking that is, thinking in which the focus of attention begins with known data. Forward chaining can be used within an agent to generate inferences from incoming perceptions, often without a specific Akil query. Forward chaining is an inference method that makes reasoning from a problem to its solution. If the premise clause matches the situation (values TRUE), then the process will state the conclusion. Forward chaining is data-driven because inference begins with available information and only conclusions are obtained. If an application produces a tree that is wide and not deep, then use forward chaining.

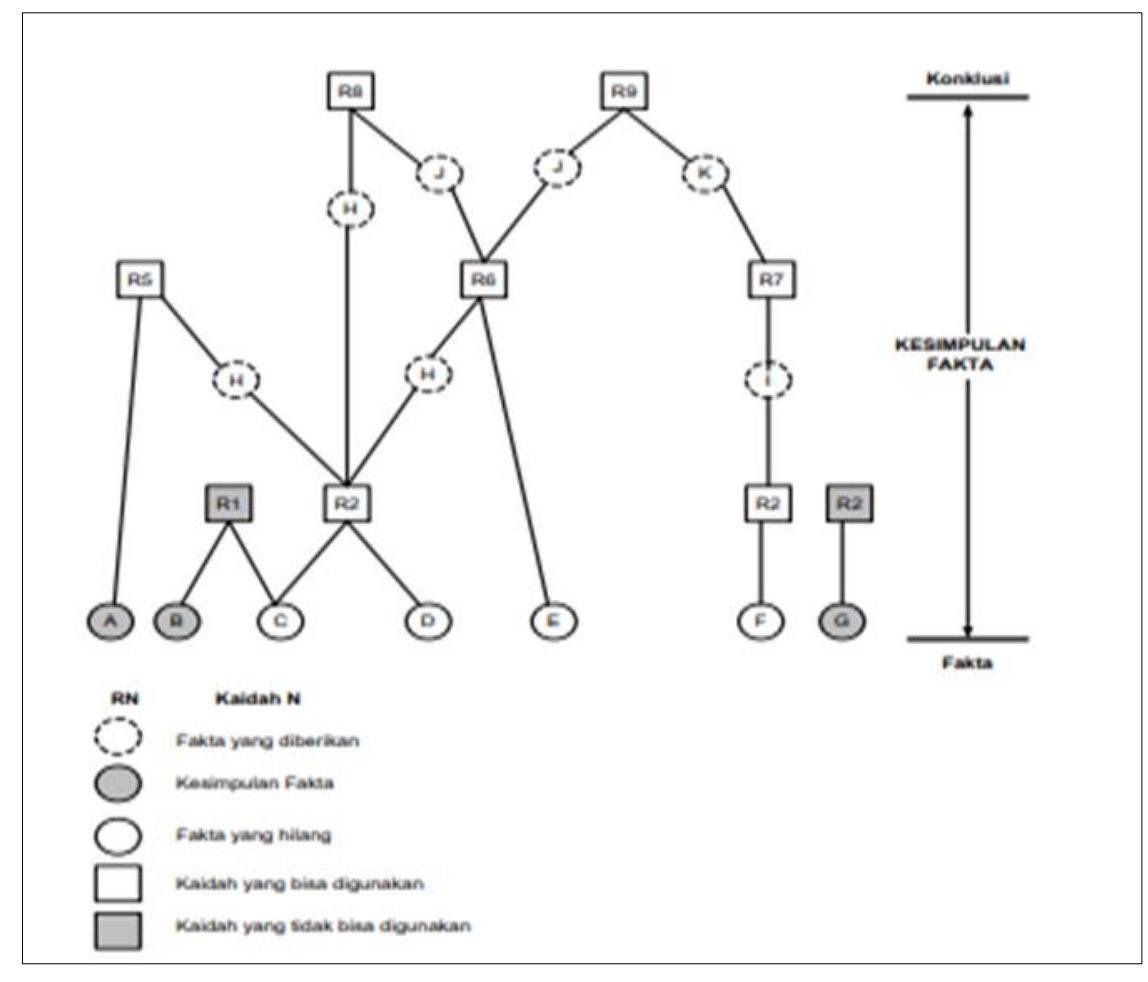

Figure 1 Forward Chaining

System Development Life Cycle (SDLC) is a series of steps used by a company in building information systems [6].

The development of science and information technology is growing rapidly. From time to time science and information technology has undergone many developments and advancements. This can be seen directly or indirectly. These developments are having an impact on all aspects of human life. One of the impacts of the development of science and information technology can be seen from the fundamental changes in the way people do management in organizations. Likewise with the tendency of computerization which is increasingly being used in various day-to-day organizational 
management matters. Research conducted by [7] is an application maker of fire safety feasibility checks with certainty factor algorithms in buildings with a medium-sized building classification to determine how good the quality of a building in the field of fire prevention and foster a sense of concern and alertness or comfort for building occupants. while working in the building. With this research [8], the current system will be designed into a web-based system which will make it easier for employees to report work and make it easier for managers to monitor work activities. In this design the author uses the Waterfall development method through sequential stages, namely requirements analysis and system design.

Singaperbangsa Karawang University (UNSIKA) is a state university as well as the first university to be established in Karawang Regency, West Java. UNSIKA was founded on February 2, 1982 by the Pangkal Perjuangan Higher Education Foundation. Since October 6, 2014 UNSIKA (PTS) has changed its status to a State University (PTN) in accordance with the Presidential Decree number 123 of 2014 concerning the establishment of the Singaperbangsa Karawang University. This change in status has become a separate motivation for all elements of the work unit within the Singaperbangsa University, Karawang in improving their services for the better. The General Bureau at Singaperbangsa University, Karwang is a structure of work units that have their respective duties and functions. One of its duties and functions is to provide facilities and infrastructure services for all activities within the Singaperbangsa University, Karawang. One of the services provided by the General Bureau of the Singaperbangsa University, Karawang is to provide facilities and infrastructure services in the form of room lending or the use of room permits to support all activities in a series of events within the Singaperbangsa University, Karawang. The density of the series of events every day makes the officers of the General Bureau of facilities and infrastructure have to record a number of the series of events carefully so that there are no schedule conflicts. Most of the series of events used the existing room facilities within the Singaperbangsa University, Karawang. Therefore, the activity of applying for a permit for borrowing the use of a room is very important, but it is still done manually. In the ongoing process, sometimes the related parties forget to write a list of room rentals and then receive an application for a space loan on the same day but different borrowers so that overlapping events occur which makes one party have to be willing to give in and change the schedule in another room or on the same day. other.

Research on borrowing space and goods that still uses a manual system has become computerized so that it can be accessed via desktop or mobile and can provide complete and efficient loan information that is stored in a database server [9]. In a study entitled Expert System Applications for Simulation of Diagnosis of Pests and Onion and Chili Plants Using Forward Chaining and a Rule-Based Approach [10]. In this research, the diagnostic simulation uses the Forward chaining method on the expert system inference engine.

The method used in developing this system uses the Waterfall method, while the system design method uses the Unified Modeling Language (UML) [9]. Another study states that System Development Research Methodology (SDRM) is used in the construction of information systems for lecture rooms/computer laboratories [11].

In this study, the author is interested in building a Space Management Application Design application using the Forward Chaining Method to make it easier for study programs, rectorates, and related divisions to make it easier if you want to know whether the room can still be borrowed to carry out activities that you want to use so that it doesn't work. there is a conflict in timing. This application was built using Laravel which can be accessed through the website so that it allows users to use this application using the WEB.

\section{Research Methodology}

Research that uses space management applications using the WEB-based Forward Chaining Method is software engineering research (research and development). Using the System Development Life Cycle (SDLC) method. System Development Life Cycle (SDLC) is a series of steps used by a company in building an information system [11].

SDLC consists of 5 (five) phases, namely:

- $\quad$ System Planning

- $\quad$ System Analysis

- System Design

- $\quad$ System Implementation

- System Operation and Support 
The expert system method used in this study is the Forward Chaining Method, which is a chain that is sought or passed from a problem to obtain a solution called forward chaining [12]. Forward chaining is an example of a general concept, where the focus of attention on reasoning starts from known data [13]. From this definition it can be concluded that forward chaining is a fact-finding method where the focus of reasoning starts from known data and ends at a solution.

The System Development Research Methodology by [14] will be used and adapted to complement this research. Methodology is an important part of application developers because it can explain the capabilities and development of the system. This methodology has six phases, namely Problem Identification, Data Collection, Data Analysis, Design, Testing, Evaluation.

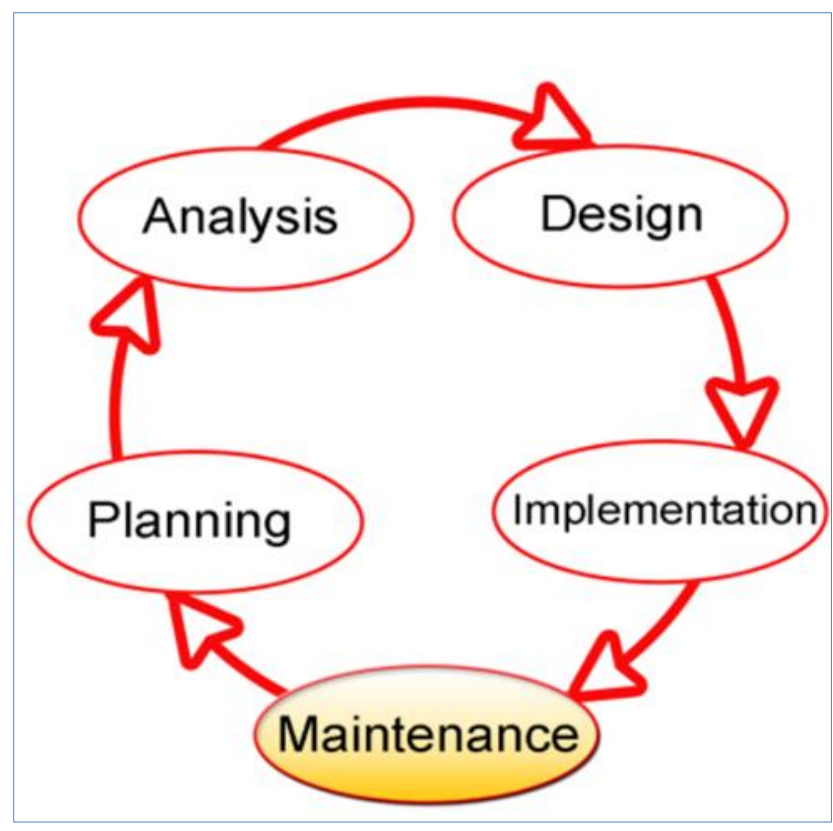

Figure 2 Sistem Development Life Cycle

Figure 3. shows the methodology that will be adapted for the design of information systems in this study, as follows:

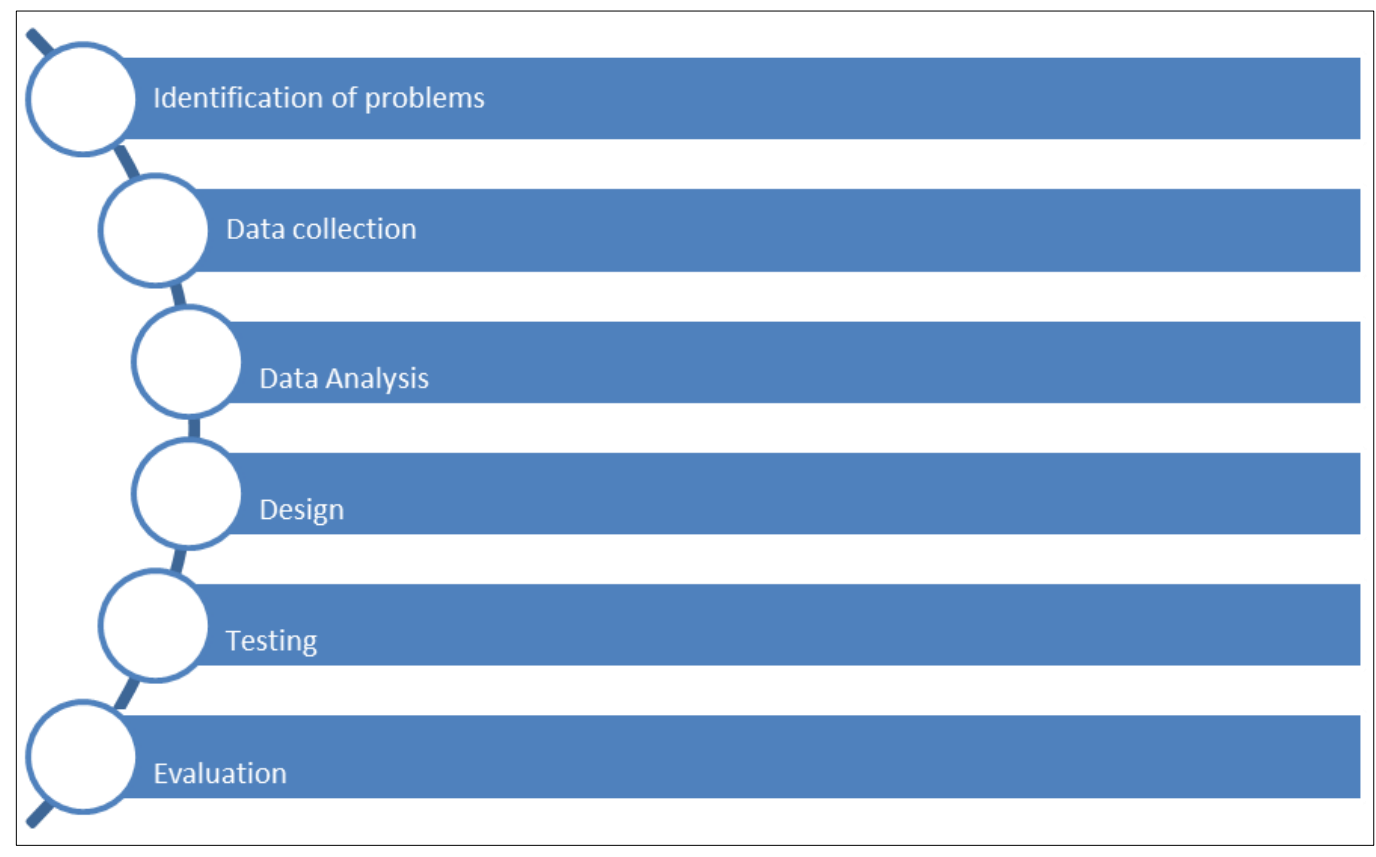

Figure 3 Research Method 


\subsection{Identification of problems}

It is looking for possible problems to be raised with several solution options to do to solve the problems at hand.

\subsection{Data collection}

Data collection is a phase where after we identify problems that can be used. The data was obtained from the General Bureau at Singaperbangsa University, Karawang.

\subsection{Data analysis}

After the data is obtained from the general bureau, there are hundreds of data, so it enters the phase to be analyzed whether the data falls into the categories needed in this study.

\subsection{Design}

In this phase, the design is carried out to be able to create an application for information systems such as use cases and activity diagrams.

\subsection{Testing}

After the design phase, enter the testing phase, the phase where to try the application that has been made to the user.

\subsection{Evaluation}

This phase is the last phase after the testing phase is run to see how much performance can be used, whether there are gaps for errors.

\section{Results and discussion}

The result of the research is that the forward chaining method can work in an expert system application that can detect the number of rooms that have not been used by other divisions through the room table displayed by the system to the user. This expert system requires information or data about all loan schedule tables available at Singaperbangsa University. With the information or data that has been obtained, the expert system can work with reasoning techniques to solve the problem of a schedule from the existing rooms. Loan Room Table:

Table 1 Table of Loan Room

\begin{tabular}{|c|l|c|}
\hline No & \multicolumn{1}{|c|}{ Room Name } & Code Description Room \\
\hline 1 & Location & T1 \\
\hline 2 & Floor Description & T2 \\
\hline 3 & Lecture Room Code & T3 \\
\hline 4 & Capacity & T4 \\
\hline
\end{tabular}

Whereas the inference engine process describes the search process to determine the right conclusion. The inference engine will receive response data from general user answers, then process the appropriate knowledge base. The method used is forward chaining or can be called (forward chaining).

\subsection{Main Page for Lecturers}

The lecturer login menu page is a page to enter the lecturer menu page entering the username with the registered NIDN and registered password. 


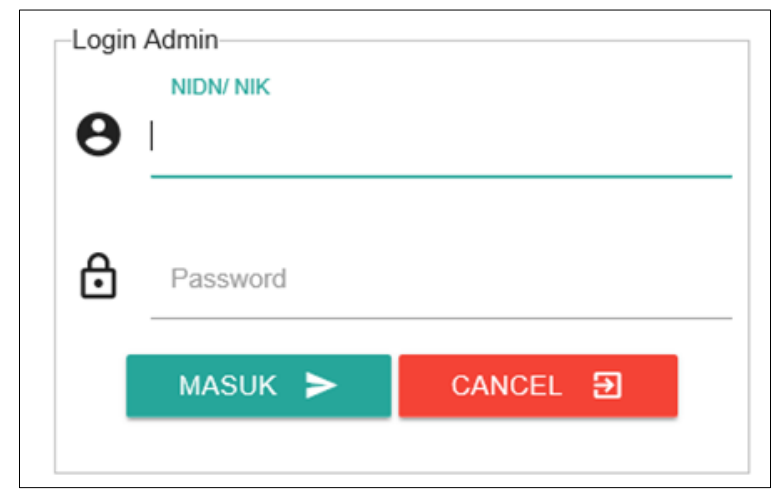

Figure 4 User Main Display

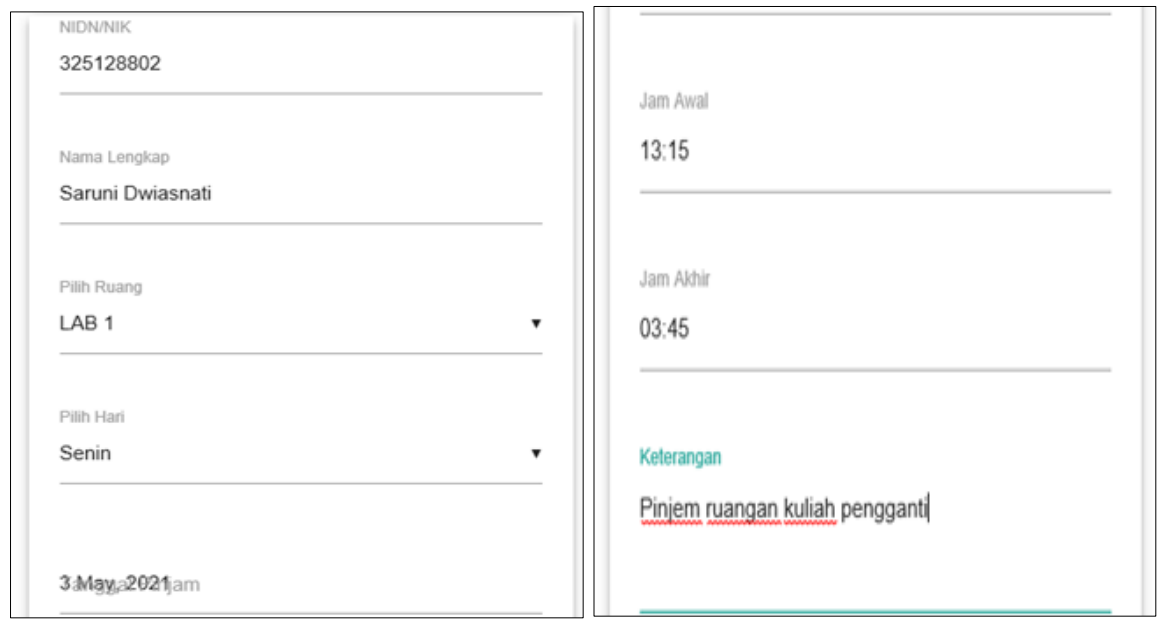

Figure 5 User charging display

The user entry display page is a page for a lecturer to fill in the data needed to borrow the room they need in accordance with the filling rules.

\subsection{Homepage for Superadmin}

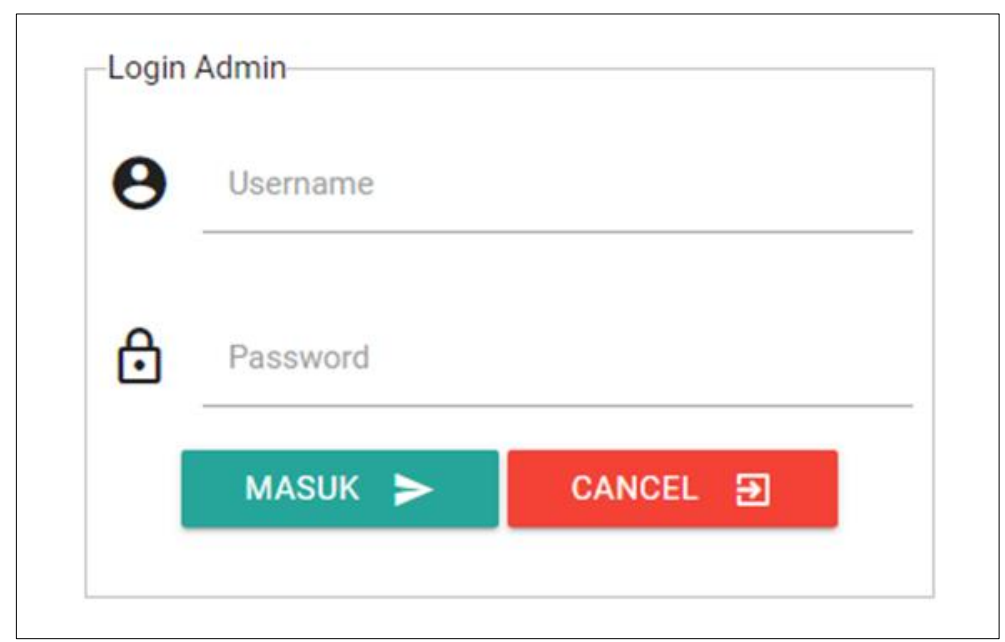

Figure 6 Superadmin Main Menu

This page is the starting page when the user wants to enter what permissions are there. The user here is a PIC who is responsible for providing room loans made by lecturers. 


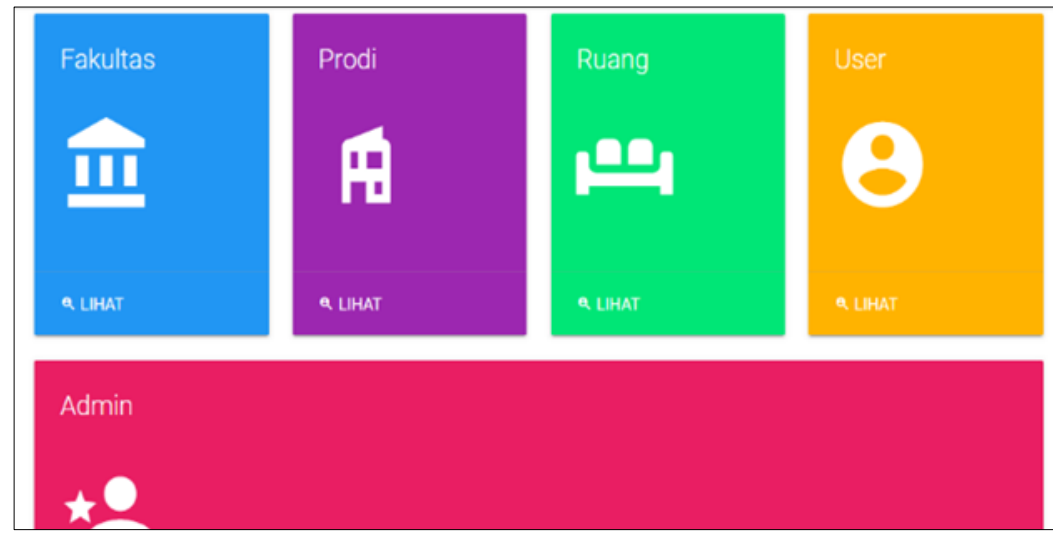

Figure 7 Superadmin Menu Page Display

This page is a menu page that contains the parameters for filling in the room loan.

\begin{tabular}{|l|}
\hline Program Pasca Sarjana \\
\hline Bahasa dan Sastra \\
Peternakan \\
\hline Ilmu Hukum \\
\hline Sains dan Teknologi \\
\hline Ekonomika dan Bisnis \\
\hline Ilmu Pendidikan \\
\hline
\end{tabular}

Figure 8 Display of the Faculty Menu Page

This page is a menu page that is displayed from the Faculty menu.

\begin{tabular}{|l|}
\hline Magister Manajemen \\
\hline Magister Pendidikan IPS \\
\hline Pendidikan Bahasa Inggris \\
\hline Pendidikan Bahasa dan Sastra Indonesia \\
\hline Sastra Inggris \\
\hline Peternakan \\
\hline Ilmu Hukum \\
\hline Pendidikan Matematika \\
\hline
\end{tabular}

Figure 9 Display of Study Program Menu Page

This page is a menu page displayed from the Study Program menu. 


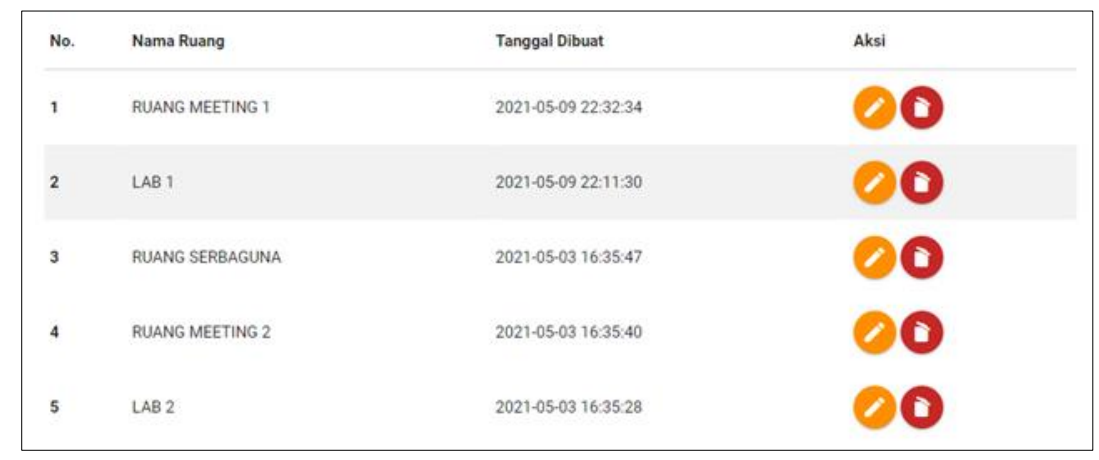

Figure 10 Space Menu Page Display

This page is a menu page that is displayed from the Space menu.

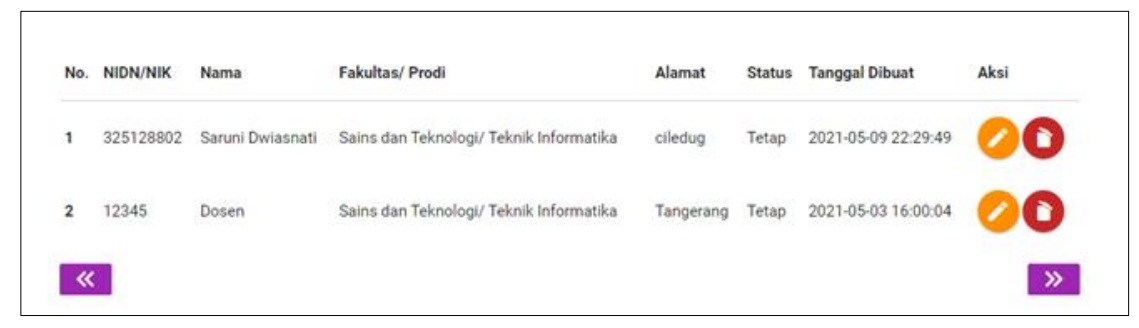

Figure 11 User Menu Page Display

This page is a menu page that is displayed from the User menu, which contains the names of users who use the application.

\section{Conclusion}

With this web-based expert system application, it can make it easier for users who need to borrow rooms at the University to find out the number of rooms that can be used and which rooms have been booked by other users for teaching purposes, other meeting purposes. The entire expert system must have good maintenance so that it can be used continuously so that this expert system can be used optimally according to its function, in this study the expert system must always be updated from system aspects and aspects of the knowledge base in it, especially the number of rooms available in universities and future research needs to increase the base from a WEB base to a MOBILE base and have notification information if the room has been booked by the admin of this application.

\section{Compliance with ethical standards}

\section{Acknowledgments}

Praise and gratitude we pray to the presence of God Almighty for all His graces and gifts so that this research on Domestic Cooperation can be completed properly. We do not forget to thank the big family of The Faculty of Computer Science, Mercu Buana University and Faculty of Computer Science, Singaperbangsa University, Karawang, especially Puslit Mercu Buana University for providing research funding support. I also thank my husband and children for their support during this unprecedented time to carry out this research.

\section{Disclosure of conflict of interest}

Authors declare no conflict of interest.

\section{References}

[1] Arhami M. Konsep Dasar Sistem Pakar. Yogyakarta: Andi. 2005. 
[2] Gary B, Shelly Thomas J Cash, Harry J. Rosenblatt, System Analysis and Design 3rd Edition, Course Technology. 1998.

[3] Ilham Khasbi, Fajar Nugraha, Syafiul Muzid. Sistem Informasi Peminjaman Ruang dan Barang di Univeristas Muria Kudus berbasis WEB menggunakan Fitur SMS Notification. Jurnal SIMETRIS. 2016; 7. 2.

[4] H. Nuriyanto, S. Rudiarto, I. Komputer, and U. M. Buana, "Rancang bangun aplikasi pemeriksaan kelayakan keselamatan kebakaran pada bangunan gedung,” vol. 9, pp. 70-80, 2020.

[5] B. Priambodo and Y. Jumaryadi, "Sosialisasi Penggunaan Aplikasi Sistem Pakar Diagnosa Covid 19 Dengan Deteksi Ketidakjujuran di Meruya Utara," pp. 16-22, 2020.

[6] Jim HMH. The Future of mobile technology and mobile wireless computing, Emerald. 2004.

[7] Hari Nuriyanto dan Sabar Rudiarto. Rancang Bangun Aplikasi Pemeriksaan Kelayakan Keselamatan Kebakaran Pada Bangunan Gedung. Jurnal Format. 2020; 9(1).

[8] Kapung Rizki Siregar dan Nur Ani. Perancangan Sistem Reporting Kerja Karyawan Berbasis WEB Pada Ruangan Network Operation Center Bagian Front Office (Studi Kasus: Network Operation Center XL Axiata). Jurnal Format. 2019; 8(2).

[9] Jogiyanto HM. Analisis dan Desain Sistem Informasi, Andi Offiset, Yogyakarta. 2005.

[10] McLeod JR. Sistem Informasi Manajemen, Edisi ke-7, Edisi Bahasa Indonesia, Jakarta: PT Prehallindo. 2005.

[11] Rendra Gustriansyah, Nazori Suhandi. Konferensi Nasional Sistem Informasi. STMIK Dipanegara. Makassar. Hal. 2014; 64-68.

[12] Russell SJ, Norvig P. Artificial Intelligence: A modern Approach (Third Edit). New Jersey: Pearson Education. 2010.

[13] Sasmito, Ginanjar Wiro. Aplikasi Sistem Pakar Untuk Simulasi Diagnosa Hama dan Tanaman Bawang Merah dan Cabai Menggunakan Forward Chaining dan Pendekatan Berbasis Aturan, Semarang. 2010.

[14] Turban E. Decision Support System and Expert System. New Jersey: Prentice-Hall, Inc. 1995. 